Erika Loucanova,

Ph.D., Technical University in Zvolen, Slovakia

(iD) ORCID ID, 0000-0003-0505-3251,

email: loucanova@tuzvo.sk

Miriam Olsiakova,

Ph.D., Technical University in Zvolen, Slovakia

(iD) ORCID ID, 0000-0002-3137-1774,

email: olsiakova@tuzvo.sk

Correspondence author: loucanova@tuzvo.sk

\title{
CROWDFUNDING AS A WAY OF THE MONETARY AND FINANCIAL ECOLOGIES
}

Abstract. This paper deals with crowdfunding as a new innovative form of financing projects that implement innovations focusing on a modern, up-to-date phenomenon in the field of innovation projects. Literary sources and approaches systematization for solving crowdfunding issues indicates that crowdfunding could be understood as a new, popular and innovative way of financing innovative projects around the world. It spread in developed countries in 2008 in response to the financial crisis. Besides, the rapid expansion of the Internet and mobile Internet access provoked its expansion in developing countries. The authors described crowdfunding as a current way of financing representing an individual form of innovative projects financing. Investigation of crowdfunding is based on cluster analysis of variables such as the funds' amount collected by crowdfunding, the number of crowdfunding contributors and the average amount of contributions of individual contributors to crowdfunding. The research objects are EU-28 countries. The output of the process of object distances clustering was displayed in the form of a dendrogram. It demonstrated the graphical grouping of related objects into clusters. The interpretation of the whole analysis and its further application depends on choosing the right number level of resulting clusters. The cluster analysis findings identified four clusters of objects set on several relatively homogeneous subsets of clusters. Objects belonging to the same cluster were similar, while objects originating from different clusters - dissimilar. The authors noted that despite the innovativeness and trendiness of crowdfunding, the analysis results point to its diverse position in the EU countries. Besides, it was confirmed by the results of the applied analysis. Presented clusters point to the different number of contributors and the average value of funds spent on innovation through crowdfunding at various average contributions from one contributor. Therefore, the countries successfully applying this innovative way of innovative projects financing were the United Kingdom, France and Germany, and EU countries that realized this way of financing to a lesser extent.

Keywords: cluster analysis, crowdfunding, innovation, innovation project financing.

Introduction. Nowadays, the model of market dependence and high level of technology and mechanization dominate. They lead to both a high level of production per production unit and high capital investment in innovation. With the increase of computing power, there has been a change in tempo acceleration, at which new information technologies are built (Van der Ploeg, 2009). The tempo of changes in such a fast time puts pressure on both companies and customers, creating increasingly sophisticated innovations. It is necessary to finance their implementation (considering their size) by innovative forms of financing, as companies' own resources are limited. In the paper, project financing is characterized as obtaining financial resources for the implementation of innovative projects. The required capital's size and structure are derived from the innovation project's financial needs and the financial resources that the project manager could obtain in the given conditions. Development in communication technologies has caused both the development of public relations practices and formating new areas in practice. Now, public relations can reach individuals from various aspects and transmit private messages to individuals through

Cite as: Loucanova, E., \& Olsiakova, M. (2021). Crowdfunding as a Way of the Monetary and Financial Ecologies. Marketing and Management of Innovations, 1, 21-29. http://doi.org/10.21272/mmi.2021.1-02 
new technologies and innovative projects financing, where a new way of financing based on communication technologies is created. It applies to crowdfunding, too (Seyfi et al., 2017).

Crowdfunding presents a method on how to obtain money and finance to capitalize on various projects. Considering possibilities provided by the Internet and software opportunities, subjects who seek funds for project financing reach a potentially varied audience that has a teamwise designation the «crowd». Experts, lawyers, and makers of the policy usually describe crowdfunding as having "alternative», «disruptive», and «democratizing» characteristics. These features also result from the concept of monetary and financial ecologies, which assumes that the processes of capitalizing on the crowd are variegated, intermediated and uneven (Langley and Leyshon, 2017). Thus, it is a new, digitally rendered economic space that could challenge established funding practices. To reach a critical progress in the crowdfunding economy, it is necessary to develop the idea of «ecologies», which is elaborated in the literature dealing with money and finances. Although academic research in the field of crowdfunding is currently reduced, it is still receiving more attention. The focus is on the area of digital humanities and business studies. The financial and monetary ecologies issues were initially developed to consider the endurance of «relic» forms of financial issues during the 1990s. It consisted of expensive moneylending applied from door to door and households' insurance in miserable urban regions in the United Kingdom (Leyshon et al., 2004, 2006). These unfavourable agreements overcame the change related to delivering financial products at-a-distance and evaluating the market. There were problems associated with risk assessment and payments collection associated with economic precarity. In this case, the ecology idea applies an approach to money and finance geographies without consideration of monetary and financial systems operations to be singular and defined by the space and time logic of a global capital circuit. Money and finance geographies include discrete and dynamic constitutive ecologies. In turn, the ecologies above consist of specific configurations. They are more or less reproducible over time. These relational processes, which entail distinctive combinations of financial knowledge, institutional and intermediary techniques and expert and popular subjectivities, unfold across space and evolve concerning geographical difference. Therefore, distinctive ecologies emerge in various places (Langley and Leyshon, 2017; Loucanova and Nosal'ova, 2020).

According to Zhao et al. (2017), crowdfunding has become a new, popular, and innovative way of financing innovative projects worldwide. Therefore, crowdfunding platforms and their supporters try to attract new participants in innovative projects while new visitors and contributors to innovation financed through crowdfunding. They also seek to explain and understand the purpose of this funding, which is especially important to increase fundraising projects' success (a fundraising project is a fundraising project). As it is presented by Massolution (2015), crowdfunding fundraising has doubled worldwide.

There is still no accurate specification of what caused the emergence and rise of crowdfunding. However, the emergence of new web technologies and the financial crisis have significantly helped.

Crowdfunding spread in developed countries in 2008 in response to the financial crisis. However, through the rapid expansion of the Internet and mobile access, it has spread to developing countries. (Crowdfunding, 2018). At the time of the crisis, it was complicated to finance projects through loans. Their acquisition was significantly limited in the bank. In most cases, financing from own resources was also almost impossible. Therefore, it was only a matter of time when people begin to present their visions, thoughts, ideas and projects via the Internet. However, these plans could not be realized because they could not raise enough money, even by a website presentation. Crowdfunding has huge investment potential. Given the above, crowdfunding is one of the main sources of innovative projects' funding in crisis times. The fact that we are currently in a crisis caused by a pandemic, which has a major negative impact on the economy in many countries, as well as that crowdfunding is innovative (but it faces obstacles such as contributors' concerns or quality of innovation, low number of contributors, etc.), led us to carry out the following research. Thus, this study aims to analyze crowdfunding as an innovative way of financing innovation regarding the number of financial resources collected by crowdfunding, the number of 
crowdfunding contributors and the average amount of individual contributors to crowdfunding in each EU28 country through the cluster analysis.

Literature Review. Currently, it is the age of the Internet. Crowdfunding represents a new trend for small business owners and individuals to find funds on the Internet, which currently presents a tool influencing the market and its users' decisions. Notably, by Salajova (2017), crowdfunding is a heterogeneous category of alternative finance, which could be used to finance various non-profit and business activities. Besides, crowdfunding could be defined as the collective effort of several individuals who are willing to share and contribute their resources to support projects initiated by other people or organizations. The whole course of projects and their financing is carried out via the Internet. Individual projects are funded by small contributions from many individuals (Buyesere et al., 2012).

Bone and Baeck (2016) understand crowdfunding as a new form of financing. In turn, projects are financed through many small donations or investments by a large group (the crowd) instead of large donations or investments from one or more traditional investors. Crowdfunding is a tool for start-up entrepreneurs to obtain funds. It is difficult for these entrepreneurs to receive funds from the banking sector because they need to prove the property guarantee. Besides, getting subsidies is sometimes difficult for start-ups in which they do not orient themselves (Loucanova and Lackova, 2018). Thus, obtaining funding for the implementation of innovative projects is its primary role.

Its secondary task is to define an interest in the project and a particular vision for potential customers. Moreover, it is essential to analyze the recorded and processed data to determine the sense for seeking a solution for its implementation, even in case of little project chance to succeed according to the contributors. The advantages of crowdfunding are the financing of innovative projects and supporting the marketing concept. Notably, only a campaign with the right marketing elements can succeed and achieve its intended goal. Herewith, the mentioned above are the reasons that contribute to the massive development of this new innovative way of financing innovative projects. It stands to mention other advantages, such as:

- Minimal financial risk. Most of the crowdfunding platforms do not charge any fees for publishing the campaign. They only charge a percentage of successful projects without fees in advance. If the campaign is not successful, it will receive feedback from visitors. Therefore, additional measures could be taken to renovate the project and presented it on the platform again to impress investors. However, this approach also has its risks. Contributors could identify a failed project and then deny the contribution, as it has already failed once. Nevertheless, it is also considered to be the biggest advantage of crowdfunding to get advice and proposed changes in the general public campaign. Some contributors want to help so actively that they are willing to create promotional means to support the project and share it on their social networks with their friends and acquaintances (Young, 2013).

- Everything under control. The campaign creator is fully responsible for the process, including price, timing, delivery, creative vision, marketing and communication with customers.

- Full ownership maintaining. The project and business remain fully with the founder, which is significantly different from other forms.

- Testing the popularity of the model through a small prototype or pre-production materials.

- No documenting. In traditional investment scenarios, entrepreneurs have to document detailed business plans and budgets, substantiated applications for funding and various other formalities. It is often associated with a possible risk of success. When financing through crowdfunding, all we need to do is get the general public's attention and explain why they should invest in the project. In a successful case, it is possible to exceed the target of financing.

- Useful advice from contributors who want the project to succeed. In turn, the contributors become «marketing team» promoting the project to their friends and acquaintances (Steinberg, 2012). 
- However, crowdfunding has potential risks. Each participant should be aware of possible risks and consider them performing crowdfunding to avoid possible problems. Among the most common disadvantages of crowdfunding belong:

- Time, knowledge, and skills needed to create an effective communication strategy and campaign.

- The project is available to the general public. Project owners must disclose valuable commercial information that may undermine the ability to protect intellectual property rights or business strategies.

- The need for technology in developing countries is an entry barrier.

- Lack of supportive regulatory environments without clear rules (NBS, 2017).

- Underestimating costs needed to create a successful project. In terms of time, various additional administrative costs need to be considered at the beginning.

- Competition. A few investors are focused on the specific type of projects. Thus, it is necessary to ensure the precise reworked and thorough project entering the crowdfunding platform.

- The risk of fraudulent platforms.

- Social media awareness. Although the campaign is presented through a crowdfunding platform, most contributors could access it through other websites or social networks. Thus, the authors should have the requisite knowledge to present their campaign on other sites successfully. In turn, it allows them to take care of the project during the whole process actively or answer questions and perceptions of their potential contributors (Young, 2013).

Buckingham (2015) assumes that a crowdfunding explosion is expected in the coming years in terms of the number of crowdfunding platforms and the amount of money raised for potential projects. Dresner (2014) presents: «The beauty of crowdfunding is its pure simplicity - to create what people want».

«Through crowdfunding, it is possible to finance various types of projects, such as works of art, various charitable and philanthropic initiatives, public projects, innovation, research and development or other business plans» (Slavik et al., 2015), not excluding eco-innovations, which are currently of great importance. In principle, eco-innovation presents the selection of suitable materials, processes and distribution methods with less energy consumption, lower consumption of natural resources and burden on the environment. At present, considering the growing customers' interest, eco-innovations represent required innovations, but not the necessary ones, which make them a tool for business competitiveness. Therefore, it is appropriate to use crowdfunding for innovative projects focused on eco-innovation supporting sustainable development.

Crowdfunding provides innovation in enabling businesses to contract with consumers before investing in innovation. When aggregate demand is uncertain, this improves the screening of valuable innovation projects. Crowdfunding enables consumers to implement deferred payments actively, thus managing moral hazard. Popular group funding platforms offer schemes that allow consumers to do so through conditional pledge behaviour. Efficiency is sustainable only if the expected revenues exceed the agency's costs associated with business incentives problems. By reducing demand uncertainty, crowdfunding promotes prosperity and complements traditional business innovation financing, which focuses on moral hazard control.

Dushnitsky et al. (2016) researched the creation of crowdfunding platforms in the case of 15 European countries. The findings showed that creating a crowdfunding platform varies from country to country regarding religion, tradition, or customs. Factors influencing the creation of the platforms in European countries provides four crowdfunding models:

1. Donation-based crowdfunding.

2. Rewards-based crowdfunding.

3. Lending-based crowdfunding.

4. Equity-based crowdfunding. 
Donation-based crowdfunding. The contributor donates funds to fulfil a specific goal without expecting any existential reward. The real reward for the contributor is the good feeling of supporting a charity project.

Reward-based crowdfunding. The contributor provides the funds in anticipation of a reward, which may be in the form of a discount or a free product or another service provision, but never in the form of a financial reward. This form of crowdfunding is most often used to support the arts and creatives (film, music, books), technology or various organizations. Contributors receive a purchase agreement for a product or service as a reward for their investment.

Lending-based crowdfunding P2P (peer to peer) is the fastest-growing crowdfunding type with up to $73 \%$ market share. A person lends money to individuals or companies for interest. There are platforms focused exclusively on socially oriented loans, but most work as commercial platforms in direct competition with other financial intermediaries (Crowdfunding, 2018).

Equity-based crowdfunding. This financing model can be the most complicated. Notably, it is recommended to obtain professional legal advice if we decide to use this form of financing. Understandably, this form is the least popular because the contributor no longer has $100 \%$ ownership of the project received on the market (Buckingham, 2015).

This publication presents (in addition to the above) two other models:

1. Pre-sale of products. Contributors provide funding for a product that does not exist yet but contributing they could buy it in advance.

2. Securities. This crowdfunding model's development is very slow, as it has significantly more pitfalls than other models.

At present, crowdfunding is a commonly used tool to finance innovation by entrepreneurs. Crowdfunding could be understood as one form of open search (active search of foreigners' ideas). In addition to open search, supporters also generate awareness of the mass-funded product. Supporters of crowdfunding could be considered the earliest possible adopters, who may be even more valuable than traditional early adopters. The results signify that the amount of funding raised during a collective funding campaign doesn't significantly impact later performance of innovation with collective financing in the market, while the number of supporters attracted by the campaign does. The depth of open search (intensive external drawing) increases the performance of the product market. In contrast, open search width (drawing from many external sources) evokes a radically innovative focus (Stanko \& Henard, 2017).

Methodology and research methods. The paper deals with the issue of crowdfunding as an innovative tool for financing innovation. The study's secondary data were selected from a database of crowdfunding usage data on the world's largest crowdfunding platform - Kickstarter (2018). The cluster analysis was used to fulfil the main goal, specifically as a hierarchical cluster method using an agglomerative approach. It means that at the beginning, each object of the research was considered as a separate cluster and gradually merged in pairs into sub-clusters from the most to the least similar objects until the result is one cluster. Measures of similarity are used to examine the similarity of objects, but mainly measures of dissimilarity denoted by the symbol $\mathrm{D}$. Measures of distances are used for quantitative data basing on the presentation of objects in space, whose coordinates represent individual variables. The most commonly used distance measure, the so-called metric, is the Euclidean distance DE. The program STATISTICA 10 was used to process the cluster analysis using the DE (Euclidean distance measures). There are two basic variables within the analyzed data set. The survey objects are $28 \mathrm{EU}$ countries. The variables are three indicators as follows: the funds' amount collected by crowdfunding; the number of crowdfunding contributors; and the average amount of contributors to crowdfunding in individual EU 28 countries, where the growth of the total intragroup sum of squares of deviations of individual values from the cluster averages is minimal.

The output of clustering object distances was a dendrogram presenting the graphical grouping of related objects into clusters. Choosing the right level for the number of resulting clusters was important for 
interpreting the whole analysis and its further application. The calculation of cluster averages and clustering of indicators were helpful.

Results. The results point to findings from analyzes of crowdfunding innovation financing on the largest crowdfunding platform. This research's primary method (cluster analysis) came to the following conclusions, as shown in Figure 1 and characterized below.

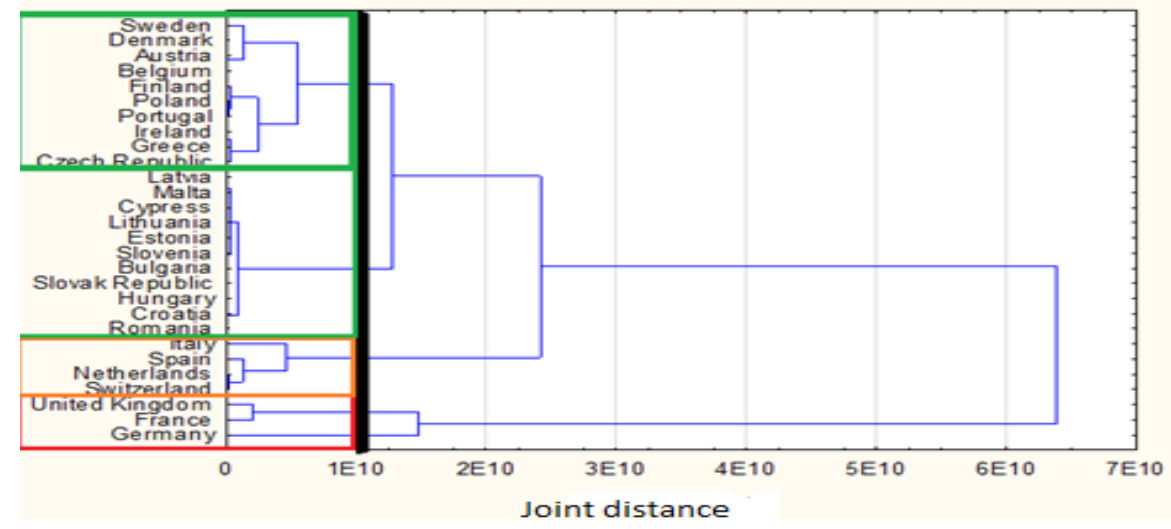

Sources: developed by the authors

Figure 1. Cluster analysis

Based on the cluster analysis, four clusters of the objects set on several relatively homogeneous subsets of clusters were identified. Objects belonging to the same cluster were similar, while objects originating from different clusters should be dissimilar, e.g. different (Figure 1 and Table 1).

Table 1. Sorting countries by clusters

\begin{tabular}{cccc}
\hline Cluster 1 & Cluster 2 & Cluster 3 & Cluster 4 \\
\hline United Kingdom & Switzerland & Romania & Czech Republic \\
France & Netherlands & Croatia & Greece \\
Germany & Spain & Hungary & Ireland \\
& Italy & Slovak Republic & Portugal \\
& & Bulgaria & Poland \\
& Slovenia & Finland \\
& Estonia & Belgium \\
& Lithuania & Austria \\
& Cyprus & Denmark \\
& Malta & Sweden \\
& Latvia & \\
\hline
\end{tabular}

Sources: developed by the authors.

The first cluster is represented by countries such as Great Britain, France and Germany. The second cluster includes the following countries Switzerland, the Netherlands, Spain and Italy. The third cluster is represented by Romania, Croatia, Hungary, Slovakia, Bulgaria, Slovenia, Estonia, Latvia, Cyprus, Malta, and Lithuania. The fourth cluster consists of other EU-28 countries: the Czech Republic, Greece, Ireland, Portugal, Poland, Finland, Belgium, Austria, Germany and Sweden. The analysis of data and the results of cluster analysis allows characterizing the individual clusters as follows:

1. Regarding fundraising by crowdfunding, Great Britain, France and Germany (the first cluster) could 
be characterized as countries with a high number of contributors and, at the same time, the high value of funds spent on innovation by crowdfunding above-average value contribution from one contributor.

2. Switzerland, the Netherlands, Spain and Italy (the second cluster) are characterized as countries with an above-average number of contributors and above-average value of funds spent on innovation through crowdfunding at the high average value of contribution from one contributor.

3. Countries such as Romania, Croatia, Hungary, Slovakia, Bulgaria, Slovenia, Estonia, Latvia, Cyprus, Malta, and Lithuania can be characterized as countries with a below-average number of contributors and a low value of funds spent on innovation through crowdfunding at the same low average value of contribution from one contributor.

4. The opposite of this cluster is cluster 4, which includes the other EU-28 countries (the Czech Republic, Greece, Ireland, Portugal, Poland, Finland, Slovakia, Belgium, Austria, Germany and Sweden). These are characteristic within the cluster in terms of fundraising by crowdfunding as the countries with a low number of contributors and a below-average value of the funds' amount of spending on innovation by crowdfunding at the same below-average value of the contribution from one contributor.

Although crowdfunding is innovative and trendy, the analysis results point to its diverse position in individual EU countries. Following the studies (MacMillan et al., 2005; Morgan and Hunt, 1994; Lambert and Schwienbacher, 2010; Kalamarova et al., 2014), contributors' confidence increases by involving them in a project within an open innovation system for creating an invention if they believe that their expected benefits outweigh the potential costs. However, contributors also make decisions based on their feelings and sympathies. Therefore, the motivation of contributors through social media is important. Liu et al. (2016) found that contributors' intangible influence plays a greater role in influencing contributors financially. It is also influenced by the fact, as described in the study by Zheng et al. (2014), that contributors support crowdfunding projects that relate to their interests. If a crowdfunding project is very popular with the public by the groups' interest perspectives, the likelihood of large participation of contributors in this project will increase. It is vital not only to create crowdfunding projects but also to develop an awareness of them and build trust in the given method of financing and promote an innovative culture not only in companies but also in society as a whole.

Conclusions. Nowadays, innovative approaches to financing innovative projects are an important part of innovation and project management. Given the market's rapid pace and the need to innovate products, they consider customer requirements in a short time and within limited resources. Crowdfunding represents the potentially greater success of these innovative projects, especially in terms of their ability to finance them, even if they combine new funding methods with traditional forms. The leaders in the use of crowdfunding among European countries are the United Kingdom, France and Germany. They represent countries with many contributors and the high value of funds spent on innovation by crowdfunding at the above-average value of one contributor. Other countries within the $28 \mathrm{EU}$ do not achieve such a positive value.

Author Contributions: conceptualization, E. L. and M. O.; methodology, E. L. and M. O.; software, E. L.; validation, E. L. and M. O.; formal analysis, E. L. and M. O.; investigation, E. L. and M. O.; resources, E. L. and M. O.; data curation, E. L. and M. O.; writing-original draft preparation, E. L. and M. O.; writingreview and editing, E. L. and M. O.; visualization, E. L. and M. O.; supervision, E. L. and M. O.; project administration, E. L. and M. O.; funding acquisition, E. L.

Funding: This research was funded by the Scientific Grant Agency of the Ministry of Education, Science, Research, and Sport of the Slovak Republic, Grant No 1/0674/19 Proposal of a model for the eco-innovation integration into the innovation process of companies in Slovakia in order to increase their performance. 


\section{E., Loucanova, M., Olsiakova. Crowdfunding as a Way of the Monetary and Financial Ecologies}

\section{References}

Bone, J., \& Baeck, P. (2016). Crowdfunding good causes-Opportunities and challenges for charities, community groups and social entrepreneurs. NESTA. org. Retrieved March, 2, 2016. Retrieved from: [Link

Buckingham, C. (2015). Crowdfunding Intelligence: The ultimate guide to raising investment funds on the Internet. LID Editorial.

Buyesere, K., Gajda, O., Kleverlaan, R. \& Marom, D. (2012). A Framework for European Crowdfunding. [Google Scholar]

Crowdfunding. (2018). Retrieved from: [Link]

Dresner, S. (2014). Crowdfunding: a guide to raising capital on the Internet. John Wiley \& Sons. [Google Scholar]

Dushnitsky, G., Guerini, M., Piva, E., \& Rossi-Lamastra, C. (2016). Crowdfunding in Europe: Determinants of platform creation across countries. California management review, 58(2), 44-71. [CrossReff [Google Scholar]

Kalamarova, M., Parobek, J., Loucanova, E., \& Trebuňa, P. (2014, May). Competitiveness evaluation of the Slovak forest industry. In Proc. 7th Int. Scientific Conf. of Int. Assoc. for Economics and Management in Wood Processing and Furniture Manufacturing (WoodEMA), Zvolen (Slovakia) (pp. 58-62). [Google Scholar]

Kickstarter. (2018). Retrieved from: [Link]

Lambert, T., \& Schwienbacher, A. (2010). An Empirical Analysis of Crowdfunding. Mimeo. Louvain School of Management, Belgium. Retrieved from [Link]

Langley, P., \& Leyshon, A. (2017). Capitalizing on the crowd: The monetary and financial ecologies of crowdfunding. Environment and Planning A, 49(5), 1019-1039. [Google Scholar] [CrossRef]

Leyshon, A., Burton, D., Knights, D., Alferoff, C., \& Signoretta, P. (2004). Towards an ecology of retail financial services: understanding the persistence of door-to-door credit and insurance providers. Environment and planning A, 36(4), 625-645. [CrossRef] [Google Scholar]

Leyshon, A., Signoretta, P., Knights, D., Alferoff, C., \& Burton, D. (2006). Walking with moneylenders: the ecology of the UK home-collected credit industry. Urban studies, 43(1), 161-186. [CrossRef] [Google Scholar]

Liu, Z., Min, Q., Zhai, Q., \& Smyth, R. (2016). Self-disclosure in Chinese micro-blogging: A social exchange theory perspective. Information \& Management, 53(1), 53-63. [CrossRef] [Google Scholar]

Loucanova, E., \& Lackova, P. (2018). Crowdfunding ako inovatívny spôsob financovania inovacných projektov na Slovensku a v Cechach. Ekonomické spektrum: recenzovaný vedecko-odborný on-line casopis o ekonómii a ekonomike,2. Retrieved from [Link]

Loucanova, E., \& Nosalova, M. (2020). Eco-innovation Performance in Slovakia: Assessment Based on ABC Analysis of Ecoinnovation Indicators. BioResources, 15(3), 5355-5365.[Google Scholar]

MacMillan, K., Money, K., Money, A., \& Downing, S. (2005). Relationship marketing in the not-for-profit sector: an extension and application of the commitment-trust theory. Journal of business research, 58(6), 806-818. [CrossRef] [Google Scholar]

Massolution, C. L. (2015). 2015CF: The Crowdfunding Industry Report. Massolution. Retrieved from [Link]

Morgan, R. M., \& Hunt, S. D. (1994). The commitment-trust theory of relationship marketing. Journal of marketing, 58(3), 2038. [CrossRef] [Google Scholar]

NBS. (2017). Pozícia NBS ku crowdfundingu - požiciavaniu formou «lending». Retrieved from [Link]

Salajova, S. (2017). Crowdfunding. Bratislava: Creative Industry Forum. Retrieved from [Link]

Seyfi, M., Soydaș, A. U., \& Güven, D. (2017). Evaluating crowdfunding from the perspective of Public Relations. Turkish Online Journal Of Design Art And Communication, 7(2), 150-162. [CrossRef] [Google Scholar]

Slavik, S., Bednar, R., Ljudvigova, I., Matuskova, R., Misún, J., Hudakova, I. M., ... \& Hvorecký, J. (2015). Podnikatel'ské modely a podnikatel'ské stratégie startupov l.: Recenzovaný zbornik vedeckých prac. Vydavatel'stvo EKONÓM.]Google Scholar]

Stanko, M. A., \& Henard, D. H. (2017). Toward a better understanding of crowdfunding, openness and the consequences for innovation. Research Policy, 46(4), 784-798. [CrossRef] [Google Scholar]

Steinberg, S., \& DeMaria, R. (2012). The Crowdfunding Bible: How to raise money for any start-up, video game or project. [google Scholar]

Van der Ploeg, J. D. (2009). The new peasantries: struggles for autonomy and sustainability in an era of empire and globalization. Routledge. [Google Scholar]

Young, T. E. (2012). The Everything Guide to Crowdfunding: Learn how to use social media for small-business funding. Simon and Schuster. [Google Scholar]

Zhao, Q., Chen, C. D., Wang, J. L., \& Chen, P. C. (2017). Determinants of backers' funding intention in crowdfunding: Social exchange theory and regulatory focus. Telematics and Informatics, 34(1), 370-384. [CrossRef] [Google Scholar]

Zheng, H., Li, D., Wu, J., \& Xu, Y. (2014). The role of multidimensional social capital in crowdfunding: A comparative study in China and US. Information \& Management, 51(4), 488-496. [CrossRef] [Google Scholar] 
Еріка Луканова, Ph.D., Технічний університет у Зволені, Словаччина

Міріам Олсякова, Ph.D., Технічний університет у Зволені, Словаччина

Краудфандинг як інструмент фінансування екологічних проєктів

у статті систематизовано науковий доробок щодо використання краудфанднигу у країнах Європейського Союзу. Встановлено, що науковці визначають краудфандинг як альтернативний шлях залучення фінансових ресурсів на реалізацію інноваційних проєктів. Авторами наголошено, що краудфандиг почав стрімко розвиватись у розвинених країнах під час фінансової кризи 2008 року. Стрімке проникнення інформаційних технологій та мобільного Інтернету у всі економічні сфрери суспільного життя обумовлюють поширення краудфандингу і у країнах, що розвиваються. 3 метою визначення рівня популярності краудфрандингу серед країни ЄС-28 авторами застосовано кластерний підхід. Критеріями кластеризації обрано: обсяг коштів зібраних на краудфандинг-платформах, кількість вкладників та середній обсяг їх внесків. Емпіричні результати дослідження дозволили виокремити чотири кластери країн, що візуалізовано за допомогою дендрограми. Авторами зазначено, що інтерпретація результатів аналізу та їх подальше застосування залежить від вибору кількості основних кластерів. Попри інноваційність та висхідну тенденцію використання краудфандингу, виявлено, що рівень його популярності відрізняється за країнами ЄС. Сформовані кластери свідчать про різну кількість вкладників, їх середній обсяг внесків та загальний обсяг зібраних коштів для фінансування інноваційних проєктів за використанням краудфандингу. Враховуючи отримані результати, встановлено, що краудфрандинг у фінансуванні інноваційних проєктів є найбільш популярним у Великобританії, Франції та Німеччині. Найменш розвинений - у країнах четвертого кластеру: Чехія, Греція, Ірландія, Португалія, Польща, Фінляндія, Словаччина, Бельгія, Австрія, Німеччина та Швеція. Це свідчить, що країнам четвертого кластеру доцільним є вивчення досвіду країн першого кластеру щодо практики його та переваг використання краудфандингу для фінансування інноваційних проєктів.

Ключові слова: кластерний аналіз, краудфандинг, інновації, фінансування інноваційних проєктів. 